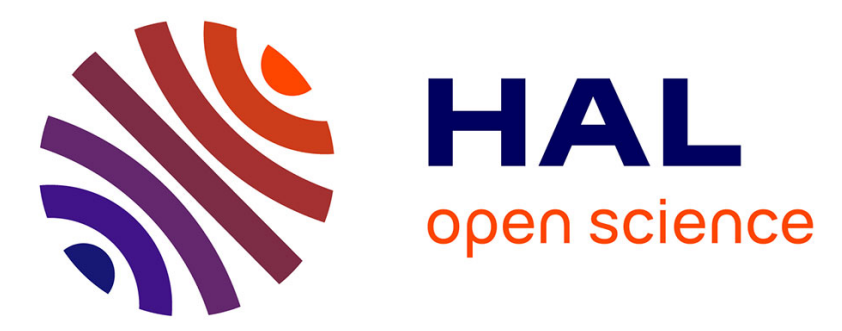

\title{
Establishment of atmospheric pollution standards for motor vehicles
}

\author{
Yiannakis Georgiades, Mireille Chiron, Robert Joumard
}

\section{To cite this version:}

Yiannakis Georgiades, Mireille Chiron, Robert Joumard. Establishment of atmospheric pollution standards for motor vehicles. Science of the Total Environment, 1988, 77, pp.215-230. 10.1016/00489697(88)90057-5 . hal-01253793

\section{HAL Id: hal-01253793 \\ https://hal.science/hal-01253793}

Submitted on 11 Jan 2016

HAL is a multi-disciplinary open access archive for the deposit and dissemination of scientific research documents, whether they are published or not. The documents may come from teaching and research institutions in France or abroad, or from public or private research centers.
L'archive ouverte pluridisciplinaire HAL, est destinée au dépôt et à la diffusion de documents scientifiques de niveau recherche, publiés ou non, émanant des établissements d'enseignement et de recherche français ou étrangers, des laboratoires publics ou privés. 


\title{
ESTABLISHMENT OF ATMOSPHERIC POLLUTION STANDARDS FOR MOTOR VEHICLES
}

\author{
YIANNAKIS GEORGIADES, MIREILLE CHIRON and ROBERT JOUMARD \\ Institut National de Recherche sur les Transports et leur Sécurité, Case 24, 69675 Bron Cedex \\ (France)
}

(Received December 14th, 1987; accepted March 18th, 1988

\begin{abstract}
First we classify the various emission standards applying to light vehicles, the conditions under which the emissions are measured and the environmental standards. We then describe the way in which a standard is established according to the basic principles and procedures involved in determining acceptable environmental concentrations in practice. We refer to the economic and political considerations involved in deciding on a standard and, as an example, to the positions adopted by the various parties concerned in France when drafting the 15.05 standard.

In response to the atmospheric pollution caused by motor vehicles, all the industrial countries have, some earlier than others, drawn up regulations designed to limit the extent of this pollution, to protect the environment and reduce the public health risk.

Both environmental and emission standards are aimed at reducing the risks to the environment and in particular to man, arising from the presence of particular pollutants. The procedure concerned in establishing these standards is a complicated one involving scientific, economic and political considerations; furthermore, there is a great diversity of standards.
\end{abstract}

\section{CLASSIFICATION OF EXISTING STANDARDS}

A standard is defined in terms of one or more limiting values and of the conditions under which the measurements concerned are carried out. These conditions vary to a great extent from one country to another so that it is difficult to compare the different limiting values.

\section{Emission standards}

These standards are aimed at limiting exhaust emissions of carbon monoxide (CO), unburnt hydrocarbons $(\mathrm{HC})$, nitrogen oxides $\left(\mathrm{NO}_{\mathrm{x}}\right)$ and particles (diesel-engined vehicles), the emission of hydrocarbons as a result of evaporation in the case of stationary petrolengined vehicles (U.S.A., California, Japan, Australia, Canada, Switzerland, Austria) and, in most countries, crankcase emissions.

The exhaust emissions standards are the most complicated and controversial of all the different standards. They include:

- Constant vehicle or engine speed or constant acceleration standards referring to the limiting concentration of the particular exhaust gas pollutant: $\mathrm{CO}$ content (EEC, Switzerland, Japan) and HC content (Switzerland, Japan) with engine idling for petrolengined vehicles and opacity of the smoke (EEC, Austria, Canada) or blackening of a filter (Japan) at certain engine speeds for diesel-engined vehicles. This type of standard takes no account of the volume of exhaust gas. 
- Standards based on the reproduction of kinematic cycles on a roller test rig. The cycles employed are of American, European or Japanese origin only (Table 1). Limiting values are expressed in $\mathrm{g} / \mathrm{test}, \mathrm{g} / \mathrm{mile}$ or $\mathrm{g} / \mathrm{km}$. For light vehicles the same values apply to both petrol-engined and diesel-engined vehicles, except in Japan where higher limits apply to the latter. The standards are applied to different stages in the life of the vehicles:

- On the occasion of the approval of new models or of any amendment to the standards when the latter are applied to new vehicles of an existing model. The interval between these two applications (to a new model or a new vehicle of an existing model) varies from 1 to 2 years in the EEC and Japan but is non-existent for most other countries, particularly the vehicle-importing ones. In the EEC the standard limiting values for kinematic cycles apply to approval tests. In the U.S.A. it is necessary to divide the standard values by a deterioration factor equal to or greater than 1 in order to obtain the approval test values. The approval may also include endurance tests, which make it possible to verify whether the emissions (measured according to the same procedure) would exceed the established limits during the life of the vehicle: up to 50000 miles in the United States, 50000 or even 100000 miles in California, and $30000 \mathrm{~km}$ in Japan. In many cases, more flexible standards apply when the manufacturer opts for endurance tests (Austria, Switzerland, Sweden) or prolonged endurance tests (California).

- As vehicles come off the production line, where they are tested on a random sampling basis. In the EEC the limits to be respected are the "production" values and in the U.S.A. the normal limiting values. It is assumed that there is a deterioration of anywhere up to $30 \%$ in the emissions of production vehicles as compared to that of the vehicles subjected to approval tests.

\section{TABLE 1}

Details of the different kinematic cycles employed for the emission standards applying to 1988 vehicles

\begin{tabular}{|c|c|c|c|c|c|c|}
\hline Cycle & $\begin{array}{l}\text { Max. } \\
\text { speed } \\
\left(\mathrm{km} \mathrm{h}^{-1}\right)\end{array}$ & $\begin{array}{l}\text { Average } \\
\text { speed } \\
\left(\mathrm{km} \mathrm{h}^{-1}\right)\end{array}$ & $\begin{array}{l}\text { Type of } \\
\text { circulation }\end{array}$ & Type of cycle & $\begin{array}{l}\text { Starting } \\
\text { conditions }\end{array}$ & Country \\
\hline ECE 15 & 50.0 & 18.7 & $\begin{array}{l}\text { Slow and } \\
\text { fluid urban }\end{array}$ & Reconstituted & $\begin{array}{l}\text { Cold plus } \\
40 \mathrm{~s} \text { idling }\end{array}$ & $\begin{array}{l}\text { EEC } \\
\text { Norway } \\
\text { Austria } \\
\text { Taiwan }\end{array}$ \\
\hline FTP 72 & 91.2 & 31.7 & $\begin{array}{l}\text { Fluid } \\
\text { urban, } \\
\text { main road }\end{array}$ & Real & Cold & Sweden \\
\hline FTP 75 & 91.2 & 34.3 & $\begin{array}{l}\text { Fluid } \\
\text { urban, } \\
\text { main road }\end{array}$ & Real & Cold & $\begin{array}{l}\text { U.S.A. } \\
\text { California } \\
\text { Norway } \\
\text { Switzerland } \\
\text { Canada } \\
\text { Australia }\end{array}$ \\
\hline EPA Highway & 96.4 & 77.4 & $\begin{array}{l}\text { Fast main } \\
\text { road, slow } \\
\text { motorway }\end{array}$ & Real & Hot & $\begin{array}{l}\text { California } \\
\text { Sweden } \\
\text { Switzerland }\end{array}$ \\
\hline 10 modes Japan & 40.0 & 17.7 & Fluid urban & Reconstituted & Hot & Japan \\
\hline 11 modes Japan & 60.0 & 30.6 & $\begin{array}{l}\text { Fluid } \\
\text { urban, slow } \\
\text { main road }\end{array}$ & Reconstituted & $\begin{array}{l}\text { Cold plus } \\
26 \mathrm{~s} \text { idling }\end{array}$ & Japan \\
\hline
\end{tabular}


- When vehicles are in use (roadside checks): $\mathrm{CO}$ content in exhaust gas with engine idling in the EEC, $\mathrm{CO}$ or $\mathrm{HC}$ content at constant engine speed in the U.S.A., and application of the complete approval test procedure in California. In some countries the manufacturers are expected to provide a guarantee (on condition that the vehicle has been subjected to normal use and maintenance): for 50000 miles or 5 years in the U.S.A., as much as 100000 miles or 10 years in California and for $30000 \mathrm{~km}$ in Japan. In California, Sweden and Switzerland the guarantee together with the application of endurance tests is associated with higher limiting values.

The kinematic cycles employed vary widely depending on the standards concerned (Table 1). In every case they are supposed to represent real kinematic cycles: those of American origin are actual cycles that have only been slightly simplified and that are accordingly very realistic, while those of Japanese or European origin are reconstituted cycles that include only constant acceleration periods, so that transitory phenomena are not fully represented. Use of the latter cycles leads to an underestimation by $15-30 \%$ of $\mathrm{CO}, \mathrm{HC}$ and $\mathrm{NO}_{\mathrm{x}}$ emissions as compared with the actual kinematic cycles [1].

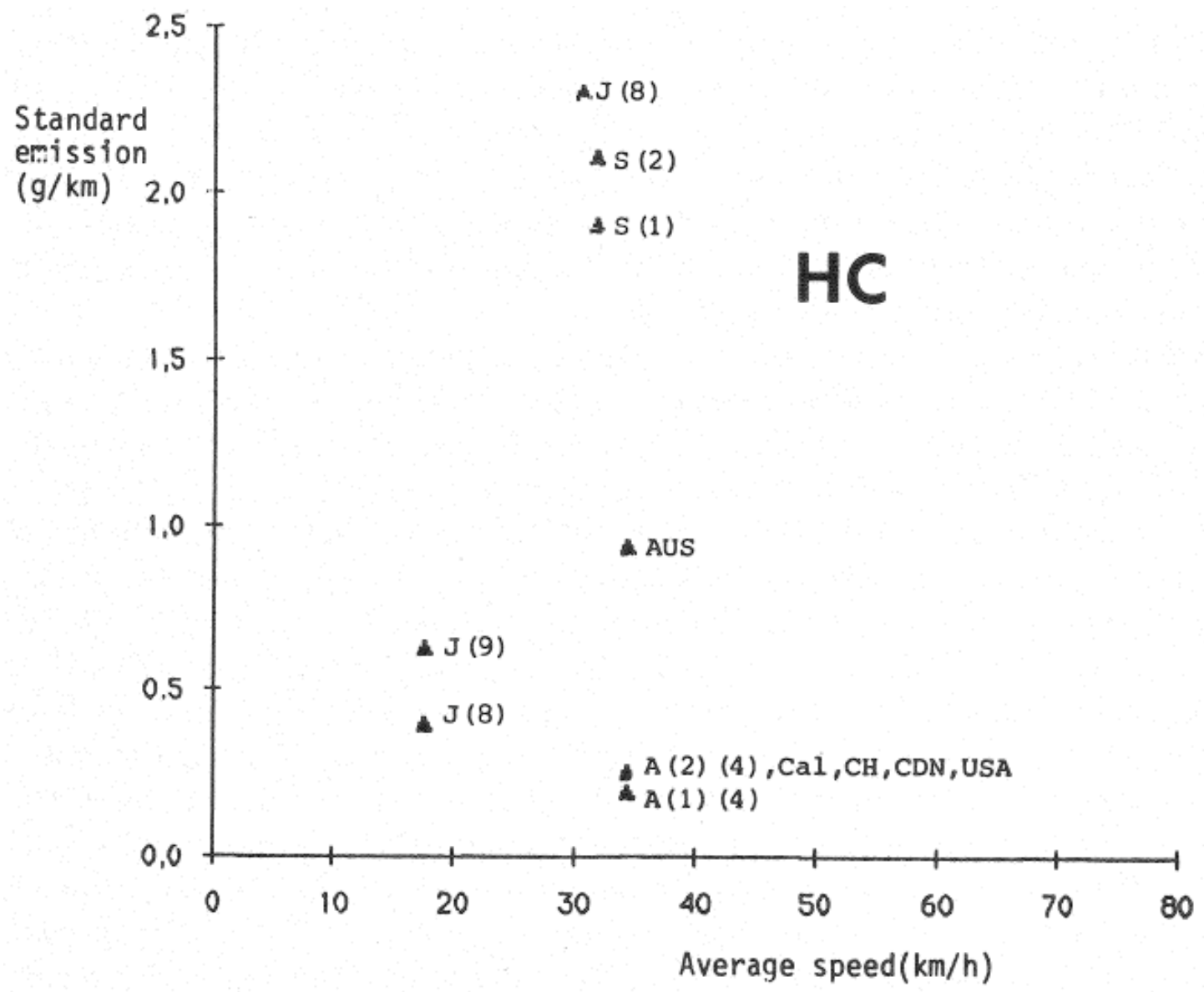

Fig. 1. Limiting values of pollutant emissions $\left(\mathrm{g} \mathrm{km}^{-1}\right)$ as a function of the average speed of the measuring cycle (production tests) for 1988 models of petrol and diesel engined cars. (1) No endurance test or guarantee, (2) With endurance test and $80000 \mathrm{~km}$ guarantee, (3) With endurance test and $120000 \mathrm{~km}$ guarantee, (4) Vehicle having a payload capacity $<760 \mathrm{~kg}$, (5) Vehicle having a payload capacity $>760 \mathrm{~kg}$, (6) Vehicle of $<1265 \mathrm{~kg}$ weight, (7) Vehicle of $>1265 \mathrm{~kg}$ weight, (8) Petrol engined vehicles only, (9) Diesel engined vehicles only. A = Austria, AUS = Australia, $\mathrm{Cal}=$ California, $\mathrm{CDN}=$ Canada, $\mathrm{CH}=$ Switzerland, $\mathrm{EEC}=$ European Economic Community, $\mathrm{J}=\mathrm{Japan}, \mathrm{N}$ $=$ Norway, $\mathrm{S}=$ Sweden, USA $=$ USA. 

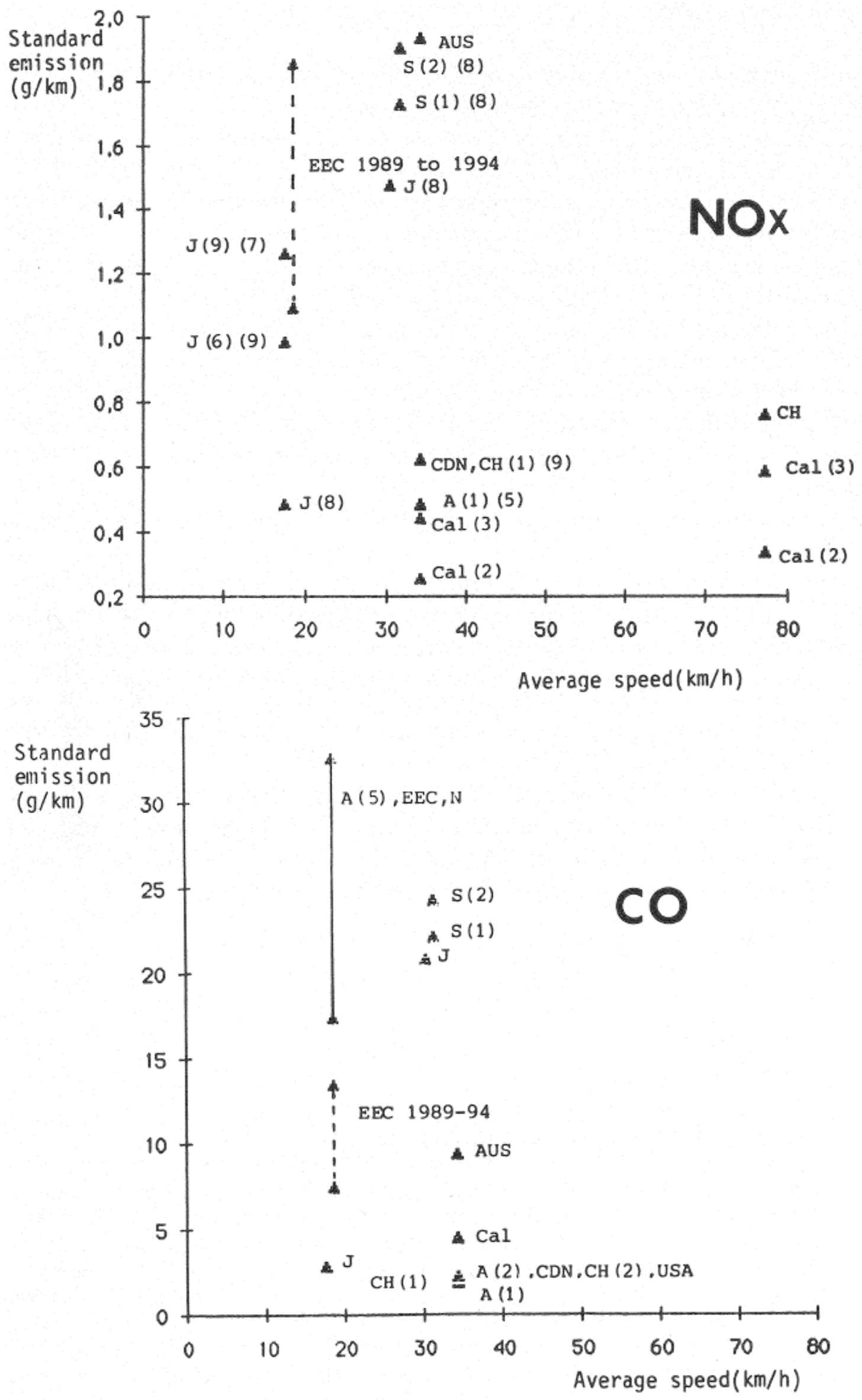
In considering the distribution of the speeds and accelerations for the different cycles, we can classify them with reference to real kinematic displacements, for example, as recorded in France [2]. Thus we can classify them with reference to four main groups of displacement: slow urban, fluid urban, main road and motorway displacements, which account for 3, 38, 50 and 9\%, respectively, of the distances covered by light vehicles in France. By doing this we can see how the European and Japanese cycles tend to be concerned with fluid urban displacements and the American ones with main road displacements (Table 1) and how no account is taken of either slow or very fast displacements. However, we know that very high levels of $\mathrm{CO}$ and even of hydrocarbons are emitted at very low speeds, while $\mathrm{NO}_{\mathrm{x}}$ is emitted more particularly at high speeds of displacement. Thus there is every justification for the introduction of a high speed kinematic cycle in the near future in the EEC.

The standards also specify the gear ratios to be employed. This is done in a unique way in the case of the ECE 15 cycle, and according to the number of gear ratios concerned in the case of the American and Japanese cycles. The actual spacing of the gear ratios, which varies from one vehicle model to another, is never taken into account and this leads to the use of engine speeds in the tests that do not correspond to actual practice, given that vehicle speed, gear ratio and engine speed are related in an unequivocal manner. This favours the vehicles with the highest gears in the case of $\mathrm{NO}_{\mathrm{x}}$ emissions since they are tested with their engines running at less than their normal speeds.

The limiting values of emission during a kinematic cycle vary very much from one country to another and are constantly being reduced. The limiting values applying to 1988 vehicles $\left(\mathrm{g} \mathrm{km}^{-1}\right)$ are given in Fig. 1 as a function of the average speed of the kinematic cycle employed for the test. A comparison of the limiting values in themselves is to be avoided: it is the combination of these values and the measuring conditions that really need to be compared.

\section{Environmental standards}

Environmental standards apply to public spaces and are aimed at safeguarding public health and protecting the material, biological and plant life environment. A distinction needs to be made between limiting values having the force of law, where any infringement leads as a matter of course to the application of measures to ensure the limits are respected, and those serving for guidance or that are regarded as no more than desirable or recommended limits, whether referred to in standards or whether they come from international organisations such as the WHO or private ones such as the German VDI.

The most important pollutants that are subject of regulations are $\mathrm{CO}, \mathrm{NO}_{2}$, lead, ozone and the oxidants; $\mathrm{HC}$ and $\mathrm{NO}$ levels are also regulated. The procedures employed to measure the levels of pollution of the environment are now fairly standardised in the various countries concerned. Only the integrating periods vary considerably from one standard to another. Two types of limit are considered:

- Absolute concentration limits integrated over periods of $1 \mathrm{~h}, 8 \mathrm{~h}, 1$ day, 3 months or 1 year.

- Limits on the distributions of average values or percentiles not to be exceeded. This is the case for NO, pollution in Holland where the standard states how a particular hourly or daily average must not be exceeded for more than a particular number of times over the year (e.g. a level of $120 \mu \mathrm{g} \mathrm{m}^{-3}$ of $\mathrm{NO}_{2}$ not to be exceeded by more than $2 \%$ of the daily average values over the year). Details of the types of standards employed in different countries are given in Table 2 (information on most of the limiting values employed is given in the basic standards and in ref. 3 ).

The standards do not differ very much as far as the integrating periods and limiting values for $\mathrm{CO}$ and lead pollution are concerned. In the case of $\mathrm{NO}_{2}$ and oxidant $\mathrm{O}_{3}$ pollution, the integrating periods differ a great deal, but the limiting values for a given integration period 
only vary over a ratio of $1-2$.

The non-standard and recommended limiting values and those put forward for guidance are the direct result of medical studies which lead to the determination of acceptable values. The difference between the latter values and the non-standard or, to a greater extent, the standard limiting values is due to the effects of economic, social or political factors, as will be discussed below when considering an example of the establishment of a standard.

TABLE 2

Details of environmental standards for different pollutants and countries ${ }^{\mathrm{a}}$

\begin{tabular}{lllllllll}
\hline Pollutant & Canada & EEC & Finland & W. Germany & Holland & Japan & Switzerland & U.S.A. \\
\hline $\mathrm{NO}_{2}$ & $\mathrm{~A}(\mathrm{~h}, \mathrm{~d}, \mathrm{y})$ & $\mathrm{P}$ & $\mathrm{P}$ & $\mathrm{A}(\mathrm{y}), \mathrm{P}$ & $\mathrm{P}$ & $\mathrm{A}(\mathrm{d})$ & $\mathrm{A}(\mathrm{d}, \mathrm{y}), \mathrm{P}$ & $\mathrm{A}(\mathrm{y})$ \\
$\mathrm{O}_{3}$ & $\mathrm{~A}(\mathrm{~h}, \mathrm{~d}, \mathrm{y})$ & & & & $\mathrm{A}(\mathrm{h})$ & $\mathrm{A}(\mathrm{h})$ & $\mathrm{A}(\mathrm{h}), \mathrm{P}$ & $\mathrm{A}(\mathrm{h})$ \\
$\mathrm{CO}$ & $\mathrm{A}(\mathrm{h}, 8 \mathrm{~h})$ & & $\mathrm{A}(\mathrm{h}, 8 \mathrm{~h})$ & $\mathrm{A}(\mathrm{y}), \mathrm{P}$ & $\mathrm{A}(\mathrm{h}, 8 \mathrm{~h})$ & $\mathrm{A}(\mathrm{d}, \mathrm{y})$ & $\mathrm{A}(\mathrm{h}, 8 \mathrm{~h})$ & $\mathrm{A}(\mathrm{h}, 8 \mathrm{~h})$ \\
$\mathrm{Pb}$ & & $\mathrm{A}(\mathrm{y})$ & & & & & & $\mathrm{A}(3 \mathrm{~m})$ \\
\hline
\end{tabular}

${ }^{a} \mathrm{P}=$ percentile, $\mathrm{A}=$ absolute limit of average value per hour $(\mathrm{h})$, day $(\mathrm{d})$, month $(\mathrm{m})$ or year $(\mathrm{y})$

\section{SCIENTIFIC DETERMINATION OF THE LIMITING ENVIRONMENTAL CONCENTRATION} [4]

The object of determining acceptable concentrations of pollutants in the environment is to be in a position to ensure the amount of toxic products discharged into the atmosphere is compatible with the good health of the exposed population.

In trying to determine such concentrations we have access to theoretical data (physical properties, structural analogies, etc.) and to the results of toxicological experiments and epidemiological inquiries. Thus we can determine the relations between administered doses and the observed effects.

We then extrapolate this data, obtained from experiments with animals or the study of particular environmental conditions (e.g. occupational exposure), so that it is applicable to the exposed population. This is done by employing a safety factor determined in most cases on the basis of empirical data so that, in theory, there will be no effects on the health of individuals exposed to the determined level of pollution.

\section{Acquisition of "objective" information}

This is a matter of obtaining as much information as possible on the cause-effect relation between the exposure to an atmospheric pollutant and the effects on health, and of being as precise in quantitative and qualitative terms as possible. The toxicity of a substance is related both to its chemical structure (e.g. presence of amine, nitrate or nitroso groups) and its physico-chemical properties, which determine the absorption, accumulation, distribution, transformation and elimination of the poison. Given this information on chemical structure and physico-chemical properties, it is possible to arrive at an approximate figure for the amount of the substance likely to be lethal and to predict the general nature of its effects and the safe degree of exposure.

Toxicological studies are then carried out involving in-vitro experiments, tests on animals and studies with human subjects. In-vitro experiments are carried out using cell cultures, microorganisms or other live reagents of human or animal origin that are isolated in laboratory recipients. These items serve as simplified experimental models where a biological process can be readily and more specifically analysed, particularly since they are not subject to the effects of other functions of the organism concerned.

Thus tests are carried out concerned with the general toxicity to the cell, with specific 
actions consisting essentially of gene and chromosome mutations and with indications of any primary DNA deterioration.

Experiments are also carried out on live animals. This is a fundamental part of toxicological research which allows us to:

- Evaluate the basic parameters of the exposure, that is the intensity and duration that can be sustained at a steady level in the absence of any spurious exposure.

- Evaluate precise toxic effects by carrying out biopsy, anatomopathology and histopathology studies.

- Predict serious effects (cancer, mutation, reproduction problems) of exposure to toxic products that have not yet been the subject of epidemiological studies.

Tests deal with both general toxicity (due to acute, sub-acute or chronic exposure) and specific toxicity (irritant and corrosive effects, sensitisation phenomena, neurotoxic effects, effects on reproduction, carcinogenic and mutagenic effects).

Toxicological studies may also involve human subjects. Such studies can be very useful as they bypass the risky animal-to-man extrapolations, and it is possible to detect subjective effects (pain, odours, sickness, etc.). They do of course raise certain ethical questions.

In addition to work with animals and biological studies there is the epidemiological approach. This is a fundamental stage in evaluating the risk to health due to atmospheric pollution since it offers a direct evaluation of the effects on the human population which takes into account the diversity of environmental conditions and individual susceptibilities.

\section{Application to the general population and to pollutant concentrations}

Once the studies have been carried out, it will be possible to determine the limiting toxicity levels corresponding to acute and possibly chronic conditions for most of the significant effects of a given pollutant or, where applicable, of a given combination of pollutants for a given animal.

Although the results of epidemiological inquiries are of great interest and allow us to determine the consequences of exposure to pollutants under actual living conditions, it must be admitted that there are still a significant number of uncertainties and there is a need for extrapolation in order to be able to define the limiting values of exposure for all or the majority of individuals according to the conception of public health in the countries concerned. Thus there is a need to decide on a safety factor that will enable us to transform the experimental level for which there are no adverse effects into a limiting value of exposure [5]:

$$
\text { Limiting value of exposure }=\frac{\text { Level having no adverse effect }}{\text { Safety factor }}
$$

According to WHO [6] this safety factor must take account of:

- Differences in susceptibility between animal and man

- Different sensitivities of human individuals

- The wide variety of pathological conditions encountered within the human species

- Differences in the evaluation of actual exposures

- Possible combined actions of different products

- The quality of the available toxicological information

It should be noted however that, at present, given that it is not possible to quantify certain parameters, the safety factor is not normally determined on any scientific basis. The usual practice is to decide on a sufficient safety margin and subsequently to note if the selected value is compatible with a healthy condition of the population as a whole. It is under these conditions that we encounter overall safety factors ranging from 1 to 50000 that are the product of the following intermediate values: 
- As a function of the effect:

Safety factor

. Where not serious:

. Carcinogenic effect:

$20-500$

. Neurotoxic effect on the autonomous nervous system:

$100-450$

- As a function of the source of the values:

. Environmental (human):

. Animal:

. Occupational:

- As a function of the type of experimental test:

. Short-term tests:

. Long-term tests:

- In order to ensure protection of the population as a whole (individual variation):

\section{Discussion: practical approach}

Although the procedure for determining an acceptable concentration starts off in a strictly scientific way, it is at present concluded on a very empirical basis. This is because it is impossible to identify all the factors associated with the uncertainties and extrapolation or to quantify precisely most of those that are identified.

Having taken steps that lead to an understanding of the toxicity of a product, it is possible to arrive at a limited understanding of the nature of the effects of the product and of the order of magnitude of the concentration producing them.

On the other hand it is much more difficult to arrive at a precise determination of the acceptable concentrations guaranteeing the health of the exposed individuals-in some cases for the whole of their lives. The determination of these concentrations calls for as much understanding of mathematical as of biological considerations, quite apart from the ethical and philosophical ones, particularly those concerned with the concept of health (a concept that really needs to be redefined).

There is no clear division between optimum conditions for health and those where health is at risk as a result of environmental exposure to potentially dangerous substances; rather, there is a progressive transition ranging from the absence of any response due to an apparent acquired tolerance, through preliminary indications of doubtful significance to a clear deterioration of health marked by obvious incapacity and real sickness. The different specialists concerned do not always agree as to the exact point in this transition where the exposure begins to affect health and hence on what is an inacceptable concentration. Clearly these differences of interpretation are of primary importance in deciding on the importance of a given item of scientific data when trying to determine acceptable concentrations. Essentially this is what influences the choice of the extrapolation and safety factors considered above for which the overall values can range from 1 to 50000 (the product of a number of intermediate safety factors). Thus, in arriving at decisions, the formal discipline of experimental work has to give way to what appears to be an empirical procedure, and the latter needs to be clarified. Technical, economic and political constraints then come into play in transforming a theoretical limiting value into a legal standard for the environment and in establishing emission standards.

\section{POLITICAL DETERMINATION OF STANDARDS: VEHICLE EMISSION CASE [7]}

Pollutant emission standards are a good indication of a country's environmental policy and of the national context in which that policy has been established. Each country or group of 
countries adopts standards as a function of the condition of its environment, the specific features of its economy (of the motor vehicle industry in the case considered here), the different parties involved and the relation between the powers that they exercise and, of course, the scientific considerations described above.

\section{Three different cases: United States, Europe and Japan}

There are two fundamental differences between the policy in force in the United States and that in force in the European Economic Community. Firstly, in the United States there was an urgent need to remedy the catastrophic situation which had arisen in California as a result of the combination of three circumstances: a significant amount of motor vehicle emission, the role of hydrocarbon evaporation and the very particular micro-climate. Secondly, given the urgency of the situation the statutory limits were based solely on the most advanced technical possibilities, or even on what were perceived as possible future technical advances. The procedure for establishing the standards seems to have been very contentious, the main disagreement being between the politicians and the technicians. The former proposed a $90 \%$ reduction of pollutant emissions, while the latter envisaged a reduction of no more than $60 \%$. The politicians had their way and this led to particular difficulties for the motor vehicle manufacturers. The reductions called for by the regulations could not be achieved on the basis of simple techniques or low cost modifications [8].

In the EEC, on the other hand, the procedure of establishing standards is based on the principle of adapting the system of regulations to existing technology. Given the progressive reduction of the limiting values of emission it has been possible, at least until recently, to avoid conflict in Europe on these matters. Thus it has been a relatively simple matter to comply with the EEC standards and the European vehicle manufacturers have only had to contend with the problems of gradually adapting to tougher standards. In addition to this, the delays allowed before introducing new directives have been sufficiently long for the manufacturers to be able to take action to comply with them.

However, the situation has changed somewhat as a consequence of the European Economic Commission's submission of proposals to the Council of European Ministers at Luxembourg in June 1985 and the final adoption of these proposals in July 1987. In its proposed directive the Commission considered that, without interfering with any other community policies, in particular the one concerning the rational use of energy, it would be possible to reduce the statutory values of emission by applying existing technology to motor vehicle engines.

The end result of the decision-making process, namely the establishment of the standard, was the product of concerted action, representations from the different parties concerned defending their various positions and a final arbitration by the politicians. The latter is of particular importance; politicians, with their personal bias and hence lack of neutrality, are the final arbitrators. They are the ones who assess the merits of taking legislative action to protect the environment and safeguard public health. They decide on the priorities and assume responsibility for emphasizing such-and-such an aspect of the problem. Their relations with the other agents concerned account for the choices they make.

The policy for the protection of the environment adopted in Japan provides us with another case. After a long period of "ecological ignorance", an outline law for the protection of the environment was adopted in 1967, but its application was delayed for a long time as it was considered inconsistent with the healthy development of the economy. However, following a certain mobilisation of public opinion, the Japanese authorities decided to suppress the economic development clause. The provisions of the outline law accordingly came into force in a phase designated as an "active technocratic one". The economic demands then had to 
come into line with the need to protect the environment.

It is very difficult to show how the political authority takes the limiting environmental values defined above into consideration in arriving at a decision and to find the relation between the limiting value and the established standard.

As an illustration of the political process involved in establishing a standard, we will consider an example of such a process in the EEC, dating back to the emergence of the acid rain phenomenon and ending with the agreement on new emission standards due to come into force in 1988 (15.05).

\section{An exceptional process to deal with an exceptional phenomenon?}

The first signs of the effects of acid rain (acidification of lakes) became apparent in the early sixties; by the nineteen-eighties there were indications in West Germany that the noticeable deterioration in their forests could be attributed to the effects of this rain. In 1982, two important events took place in West Germany: first, the specialists concerned alerted the public authorities about the deterioration of the German forests and, secondly, the Green party entered the Bundestag. West Germany then attempted to mobilise its European partners, pushing for proposals to limit motor vehicle pollutants. The urgency of the matter led to a great deal of tension within the EEC, the more so given the very divergent positions taken up by the member states. There were differences of opinion with regard to both the seriousness of the phenomenon and the role of motor vehicle pollution. Nevertheless, the Europeans were in favour of some common action. Two important decisions were taken in 1985, namely to make arrangements for the introduction and marketing of lead-free petrol by 1989 and for the reduction in the pollutant content of exhaust gases by 1988 .

France only became involved in the acid rain controversy at a late stage. Initially it was the preoccupations triggered off by German pressure that attracted the attention of the French authorities; industrial and economic considerations were by no means unimportant. Recognition of what was at stake led all the parties concerned to take up their positions: these positions and the interests they served appeared to be divergent.

The essential objective of the discussions within the community was the establishment of limits on motor vehicle pollutant emission. The motor vehicle manufacturers, their suppliers and the oil companies were the ones who would be required to reach an agreement and establish the position of France in this matter. The ecological movement expressed its opinion while the media in general and the press in particular made the matter a public issue. Public opinion was accordingly involved.

It was in this controversial and emotional atmosphere that the director of Peugeot S.A. was quoted in the 25 June 1985 issue of Le Matin as saying: "Although we have reduced pollution by $70-80 \%$, a group of hysterical people in Germany want us to accelerate the process . . this is asking the manufacturers if they are prepared to do away with thousands of jobs ... Germany is in the process of sacrificing the European motor vehicle industry, taking the view no doubt that its own industry will be spared, but they are mistaken . . . ". Incompatible positions were adopted not only by the different European parties but also by those within each country. The example of France says a lot about the relation between the different forces on this occasion.

\section{The process of coming to an agreement in France}

The debate within France was a relatively limited one compared with what took place in Germany. The French ecologists did no more than adopt positions of principle: yes to a reduction in the level of pollution, yes to lead-free petrol and yes to catalytic purification techniques-but they never started a real campaign on the subject. A French scientist explained 
this position by saying: "The ecological movement in France has concentrated all its attention on the nuclear question within a centralised organisation. In addition to this they are and continue to be concerned with problems as they affect the individual". The 'Friends of the Earth" agreed with this view and said that the position of the ecological movement was due to the French context: "The car is always regarded as a taboo subject . . ., an absolute necessity. It is part of our way of life. The extra cost of a catalyser will not lead to any change in the behaviour of the motorists. The problem is due to the fact that French industry has fallen behind in the techniques that can be employed to reduce pollution".

The position adopted by the ecologists meant that the parties involved in the French debate on reducing pollution were limited to the public authorities and the motor vehicle manufacturers.

In talking about the process of reaching an agreement, a representative of the Ministry of Transport said that: "The French position, established with the participation of the different ministerial departments concerned, is that of the government as a whole. The decision aimed at meeting the requirements to reduce pollution has been taken whilst recognising the difficulty of defining them, taking into account the state of the motor vehicle industry and the possibilities for technical innovation, allowing the time necessary for industry to implement changes and considering the real effectiveness of adopting this or that pollution standard ... In Germany the matter was essentially a political one involving the different political parties. It became a public issue and the ministers concerned very quickly took it in hand. This should be the case in other countries. Until now, projects concerned with regulations have not been a political matter. However, the passionate context of this subject in Germany went beyond national frontiers and has spread to other countries . . . this context resulted in the German government taking a very political decision, whereas in France there has not been so much pressure so that is has been possible to arrive at a decision in a more reasonable way".

A former Minister of the Environment in France (1983-1986) commenting on the French approach and the action taken with respect to the negotiations on the subject in Brussels said: "Roughly speaking the debate, which has been going on for 2 years, is about the following questions: Are we going to adopt community standards? Are we going to proceed together at the same rate or are certain countries going to proceed at a different pace, making use of tax incentives? Should large and small cars be dealt with in the same way? In fact there were a number of French approaches. The approach of the French manufacturers could be summed up as follows: 'Do as little as possible, do not make use of equipment to reduce pollution and be content with limiting motorway speeds'. Not all the manufacturers went even this far. Accordingly the French for a long time adopted a blocking position along with the Italians: the subject was avoided and advantage was taken of rules of procedure at the Council of Ministers in order to block discussion or the consideration of new solutions. I often met manufacturers' representatives in my office and looked for something that would not be too costly for French industry but that would nevertheless constitute some progress in reducing pollution. For a while the two major manufacturers in France said the same thing: 'Given that you have nothing to propose, let us be content with what we have done in the past: reduce the pollutant limits called for by the standards a little every 5 years and proceed in a progressive way rather than making a head-on attack. Meanwhile you should block any discussion of the subject . . .' In the end the manufacturers adopted a more constructive position".

The difficulties were not limited to discussions of the subject with the motor vehicle manufacturers. There was just as much, if not more, difficulty in conducting negotiations within the government. Thus there was a disagreement between the Ministry of the Environment and both the Ministry of Industry and the Prime Minister. The positions being defended were clearly defined and not very compatible. The Ministry of the Environment was concerned with the degradation of the environment and the effects of motor vehicle pollution 
on health and favoured adoption of the community standards, while the Ministry of Industry and the Prime Minister wanted to protect the weak motor vehicle industry in France and favoured a blocking of community discussions.

This conflict within the government was resolved by arbitration by the President of the Republic, which was of course no more than a decision of principle. This was followed by other arbitrations within each ministerial office, at interministerial meetings and of course during the discussions within EEC working groups as well as at the European Council of Ministers.

These few brief extracts from the discourse of certain parties involved in the subject of reducing motor vehicle pollution are very informative with regard to the decision-making process in France. This brief description of the European decision-making process and of the associated French activity shows how the acid rain phenomenon has given rise to a permanent balance of forces between the different parties concerned. Above all it has been shown how the political establishment of the standard, involving economic, industrial and political considerations, was the result of political, technical and economic arbitration.

It was during the period 1983-1985 that the drafting of the motor vehicle regulations considered here gave rise to so much reaction, taking of sides, comment, arguments and antagonism, quite out of keeping with previous experience in Europe on such occasions. In such a climate, scientifically-based decisions can be no more than a compromise and the political establishment of the standard no more than the expression and transformation of the different considerations involved. The theoretical limiting value is never discussed and is clearly not the subject of disagreement. Other considerations predominate and the respective weights of the different parties concerned have a lot of influence on the choices that are made.

\section{CONCLUSION}

We can make a clear distinction between three different rationalities in establishing standards for atmospheric pollution:

- A scientific rationality aimed at protecting the population as a whole and, where applicable, the environment against the effects of pollutants. This rationality involves both scientific discipline and an empirical approach and may result in particularly low limiting values that are difficult to attain.

- An economic or industrial rationality aimed at protecting the existence or development of the industries concerned. The limiting values resulting from this rationality depend on the dynamism of the industry and the choices made with regard to development.

- A political rationality which is the expression of the sensitivity of some social base, for example that of the electorate.

The standard is the result of, in the first place, a compromise or arbitration (more exceptionally of a concensus) between the positions being defended by the different social agents involved and, in the second place, of the balance of forces concerned with a given subject at a given moment, taking into account, in some instances, criteria that have nothing at all to do with the environment, such as European unity in the case of the 15.05 standard for motor vehicle emission.

The diversity of what is involved accounts for the great diversity of the motor vehicle atmospheric pollution standards. The scientific evaluations are accepted at the highest level of discussion. Even if these are not very precise they provide an indication of the size of the necessary reductions and hence a basis for discussion. Greater understanding of the subject, increased sensitivity and the adaptation of the industries concerned lead to periodic reductions in the limiting values, which accordingly approach those considered to be acceptable from a medical point of view. 


\section{REFERENCES}

1 R. Joumard, Emissions unitaires des véhicules légers, in Proc. Colloquium Atmospheric pollution due to transport, Paris, 1987, Pollut. Atmos., (1987) 45-56.

2 R. Joumard, M. André, J.P. Crauser, F. Badin and L. Paturel, Méthodologie de mesures des émissions réelles du parc automobile, INRETS Report No. 31, Bron, France, 1987,81 pp.

3 Anonymous, Valeurs limites d'émissions pour les polluants atmosphériques, Federal Office for the Protection of the Environment, Cahiers Environ. No. 52, Berne, 1986, 82 pp.

4 G. Froment, Détermination des concentrations et doses admissibles environnementales pour les polluants atmosphériques, principes et méthodes, Medical thesis, Univ. Cl. Bernard, Lyon I, Lyon, 1987,118 pp. plus annexes.

5 Anonymous, Considérations relatives à l'extrapolation des données biologiques pour en déduire les limites d'exposition professionnelle, Tech. Rep. No. 10, Chimie et Ecologie, Paris, 1985.

6 Anonymous, Principes de base pour l'établissement des valeurs limites d'exposition aux nuisances chimiques sur les lieux de travail, Chim. Ecol. (Paris), 1982.

7 Y. Georgiades, Voiture économique ou voiture écologique: les rationalités de l'arbitrage, Transport economy thesis, Université Lumière, Lyon II, Lyon, March 1987, 342 pp.

8 W. Berg, Evolution of motor vehicle emission control legislation in Europe-leading to the catalyst car, SAE paper No. 850384, Warrendale, U.S.A. 